AULADUNA: Jurnal Pendidikan Dasar Islam

Vol. 5 No. 1, Juni 2018, pp. 76-93

p-ISSN: 2407-2451.,e-ISSN: 26-210282

DOI: https://doi.org/10.24252/auladuna.v5i1a7.2018

\title{
ANALISIS KESULITAN BELAJAR SISWA KELAS V SD/MI PADA POKOK BAHASAN SISTEM KOORDINAT
}

\section{THE ANALISYS OF STUDENTS' LEARNING DIFFICULTY OF $5^{\text {TH }}$ GRADE PRIMARY SCHOOL ON TOPIC COORDINATE SYSTEM}

\author{
Khaeroni $^{1}$, Eva Nopriyani ${ }^{2}$ \\ ${ }^{1,2}$ Department of PGMI/UIN Sultan Maulana Hasanuddin Banten \\ ${ }^{, 2}$ Jl. Syech Nawawi Al-Bantani, Curug, Serang - Banten \\ Email: khaeroni@uinbanten.ac.id ${ }^{1}$, nopriayni@gmail.com ${ }^{2}$
}

\begin{abstract}
Abstrak
Struktur pengetahuan matematika dibangun melalui serangkaian konsep-konsep, teori-teori, atau postulat-postulat secara berjenjang. Matematika juga memiliki sifat yang konsisten, sistematis, dan logis. Fakta di lapangan menunjukkan bahwa masih banyak siswa yang mengalami kesulitan dalam belajar matematika. Karena konsep matematika berjenjang, akibatnya siswa kesulitan untuk mempelajari konsepkonsep lanjutannya. Pendekatan penelitian yang digunakan adalah penelitian kualitatif dengan model Miles and Huberman. Contohnya untuk mempelajari materi sistem koordinat, siswa terlebih dahulu harus menguasai konsep satuan dan pengukuran, urutan pada bilangan bulat, dan menggambar garis bilangan baik secara horizontal maupun vertikal. Abstraksi matematika merupakan kesulitan tersendiri yang harus dihadapi siswa dalam mempelajari konsep-konsep matematika. Guru juga dapat mengalami kendala dalam mengajarkan matematika karena sifatnya yang abstrak. Untuk itu perlu diuraikan kesulitan apa saja yang dialami siswa dalam mempelajari materi sistem koordinat agar guru dapat mengajarkan materi serupa dengan pendekatan dan cara yang sesuai dan menemukan cara mengatasi kesulitan belajar matematika dengan pendekatan reflektif.
\end{abstract}

Kata Kunci: Kesulitan Belajar, Matematika, Sistem Koordinat.

\section{Abstract}

The structure of mathematical knowledge is built through a series of concepts, theories, or postulates in hierarchy. Mathematics also has a consistent, systematic, and logic. The fact in field shows that there are students who have difficulty in learning math. Since the tiered of mathematical concepts, students aim a difficulty on learning next concepts. The research approach used is qualitative research with Miles and Huberman model. For example, to study the concept of Coordinate System, students must master the concept of unit and measurement, sequence in integers, etc. The abstraction of mathematics is a difficulty that must be faced by students in learning mathematical concepts. Teachers can also face obstacles in teaching mathematics because of its abstract nature. Therefore, it is necessary to describe the difficulties faced by students in learning the material coordinate system so that teachers can teach similar materials with appropriate approaches and find ways to solve the difficulties of learning mathematics with a reflective approach.

Keywords: Difficulty Learning, Mathematics, Coordinate System. 


\section{Pendahuluan}

Belajar adalah suatu usaha yang dilakukan secara sadar oleh seseorang atau individu dengan tujuan untuk meningkatkan kemampuan diri atau perubahan terhadap diri melalui serangkaian latihan-latihan dan pengulangan-pengulangan. Perubahan tersebut bukan merupakan kebetulan (Mulyati, 2005: 5). Belajar juga dapat artikan sebagai sebuah proses di mana sesorang atau individu mengalami perubahan perilaku sebagai akibat dari sebuah pengalaman (Susanto, 2013: 1).

Terdapat beberapa faktor yang memengaruhi seseorang atau individu untuk belajar atau mencapai perubahan. Faktor-faktor tersebut oleh Purwanto (2011: 102) digolongkan menjadi dua yaitu: 1) faktor yang ada pada diri organisme itu sendiri yang disebut faktor individual; dan 2) faktor yang ada di luar individu yang disebut faktor sosial. Faktor individual yang memengaruhi seseorang untuk belajar diantaranya adalah kematangan atau pertumbuhan baik fisik maupun psikis, tingkat kecerdasan, porsi latihan, motivasi intrinsik, dan faktor pribadi. Adapun beberapa faktor sosial dimaksud diantaranya adalah faktor keluarga atau keadaan rumah tangga, guru dan cara mengajarnya, media dan sumber belajar, lingkungan dan kesempatan yang tersedia, dan motivasi sosial (Purwanto, 2011: 102).

Faktor-faktor di atas menjadi penentu bagaimana siswa mencapai prestasi akademik-nya (academic performance). Tidak bisa dipungkiri bahwa setiap siswa pada dasarnya tentu memiliki hak untuk mencapai prestasi akademik yang baik. Akan tetapi, fakta di lapangan menunjukkan bahwa siswa memiliki kemampuan intelektual, kemampuan fisik, latar belakang keluarga, kebiasaan, dan gaya belajar yang berbedabeda dan terkadang sangat mencolok antara satu siswa dengan siswa lainnya (Nadhirah, 2017: 107).

Sementara itu, pembelajaran yang dilakukan di sekolah formal pada umumnya ditunjukan pada siswa yang berkemampuan rata-rata. Siswa dengan kemampuan lebih atau kurang akhirnya terabaikan. Siswa-siswa yang dengan kategori "di luar rata-rata" (sangat pintar dan sangat bodoh) tidak mendapat kesempatan yang memadai untuk berkembang sesuai dengan kapasitasnya. Hal ini yang mengakibatkan proses belajar yang terjadi pada diri siswa tidak selalu berjalan lancar dan berhasil. Siswa mengalami hambatan atau kesulitan belajar (learning difficulty). Kesulitan belajar tidak hanya menimpa siswa berkemampuan rendah saja, tetapi juga dialami oleh siswa yang berkemampuan tinggi. Selain itu, kesulitan belajar juga dapat dialami oleh siswa yang berkemampuan rata-rata dikarenakan faktor-faktor tertentu yang menghambat tercapainya prestasi akademik yang diharapkan. Kesulitan belajar yang dialami siswa bukan hanya pada mata pelajaran yang bersifat alamiah (natural science), melainkan juga pada mata pelajaran yang bersifat hitung-menghitung, berkaitan dengan angka dan rumus salah-satunya adalah mata pelajaran matematika.

Matematika mempunyai peranan penting dalam pendidikan terutama pada jenjang usia pendidikan dasar. Struktur pengetahuan matematika dibangun melalui serangkaian konsep-konsep, teori-teori, atau postulat-postulat secara hierarkis (berjenjang). Matematika juga memiliki sifat yang ajeg (konsisten), sistematis, dan juga logis. Fakta di lapangan menunjukkan bahwa masih banyak siswa yang mengalami kesulitan-kesulitan dalam belajar matematika. Karena siswa merasa matematika sebagai mata pelajaran yang sulit, tidak menyenangkan, bahkan momok yang menakutkan.

John dan Myklebust (dalam Sundayana, 2016: 2) menyebutkan bahwa matematika merupakan bahasa simbolis yang mempunyai fungsi praktis untuk mengekspresikan hubungan-hubungan kuantitatif dan keruangan. Sebagai bahasa 
simbolis ciri utama matematika adalah penalaran secara deduktif namun tidak mengabaikan penalaran induktif. Selain sebagai bahasa simbolis matematika juga merupakan ilmu yang kajian objeknya bersifat abstrak. Sementara itu, fungsi teoritis matematika adalah untuk melatih berpikir. Dengan kata lain, matematika adalah bekal bagi siswa untuk berpikir logis, analitis, sistematis, kritis dan kreatif.

Objek matematika bersifat abstrak, dalam hal ini merupakan kesulitan tersendiri yang harus dihadapi siswa dalam mempelajari konsep-konsep matematika. Tidak hanya siswa, guru juga dapat mengalami kendala dalam mengajarkan matematika karena sifatnya yang abstrak. Sementara siswa dapat dengan mudah memahami konsep-konsep yang bersifat konkret. Oleh karenanya, pembelajaran matematika harus dilakukan secara bertahap. Pembelajaran matematika dimulai dari tahapan konkret lalu diarahkan pada tahapan semi konkret (atau semi abstrak), dan pada akhirnya siswa dapat berpikir dan memahami konsep-konsep matematika secara abstrak (Sundayana, 2016).

Berdasarkan hasil observasi di SDIT Widya Cendekia diketahui bahwa sebagian besar siswa kelas $\mathrm{V}$ mengalami kesulitan dalam memahami konsep-konsep pada mata pelajaran matematika karena konsep matematika berjenjang, akibatnya siswa kesulitan untuk mempelajari konsep-konsep lanjutannya. Sebagai contoh, untuk mempelajari materi tentang sistem koordinat, terlebih dahulu siswa harus menguasai konsep satuan dan pengukuran, urutan pada bilangan bulat, dan menggambar garis bilangan baik secara horizontal (datar) maupun vertikal (tegak). Data empiris hasil ulangan harian materi sistem koordinat menunjukkan bahwa terdapat $60 \%$ siswa yang tidak tuntas pada materi tersebut dengan KKM 75.

Ibu Ria Mariana, selaku wali kelas di SDIT Widya Cendekia menyebutkan bahwa terdapat beberapa faktor yang mengakibatkan siswa memiliki kesulitan dalam mempelajari materi tersebut, yaitu motivasi belajar matematika yang kurang, pemahaman siswa tentang koordinat masih rendah, ketelitian siswa dalam menentukan koordinat masih lemah, kesulitan siswa dalam mengerjakan soal latihan.

Berdasarkan latar belakang di atas, maka tujuan penelitian ini untuk mengetahui kesulitan apa saja yang dialami siswa dalam mempelajari materi sistem koordinat, faktor apa yang mempengaruhinya, dan upaya apa yang harus dilakukan agar guru dapat mengatasi kesulitan belajar matematika dengan pendekatan reflektif.

\section{Metode Penelitian}

\subsection{Subjek Penelitian}

Subjek pada penelitian ini adalah Wali Kelas dan Siswa Kelas V SDIT Widya Cendekia sebanyak 34 siswa.

\subsection{Sampel dan Teknik Sampling}

Teknik pengambilan sampel yang digunakan dalam penelitian ini adalah purposive. Informan kunci atau informan awal dipilih secara purposive. Dalam penelitian ini, yang bertindak sebagai informan awal adalah Wali Kelas V SDIT Widya Cendekia. Informan selanjutnya adalah Siswa Kelas V SDIT Widya Cendekia yang ditentukan dengan teknik snowball sampling. Untuk keperluan penelitian, dipilih lima orang siswa dengan kategori siswa berkemampuan rendah. Pengategorian ini didasarkan pada hasil belajar siswa materi sistem koordinat. Selain itu, pemilihan subjek penelitian juga didasarkan atas saran dari guru kelas sebagai informan kunci yang mengetahui kondisi siswa dengan pasti. 


\subsection{Pendekatan Penelitian}

Pendekatan penelitian yang digunakan adalah penelitian kualitatif dengan model Miles and Huberman. Miles and Huberman (dalam Soegiyono, 2015: 246) mengemukakan bahwa aktivitas dalam analisis data kualitatif dilakukan secara interaktif dan berlangsung secara terus menerus sampai tuntas sehingga datanya sudah jenuh. Pendekatan ini dipilih karena penelitian ini bertujuan untuk menganalisis kesulitan belajar siswa yang dilakukan dengan cara mendeskripsikan tujuan pembelajaran yang telah ditentukan. Deskripsi sendiri merupakan karakteristik dari penelitian kualitatif.

\subsection{Posedur Penelitian}

Aktivitas analisis data kualitatif dilakukan pada saat pengumpulan data berlangsung yaitu data collection, setelah data terkumpul dari lapangan langkah selanjutnya adalah data reduction, data display, dan conclusion drawing atau verification (Soegiyono, 2015: 246).

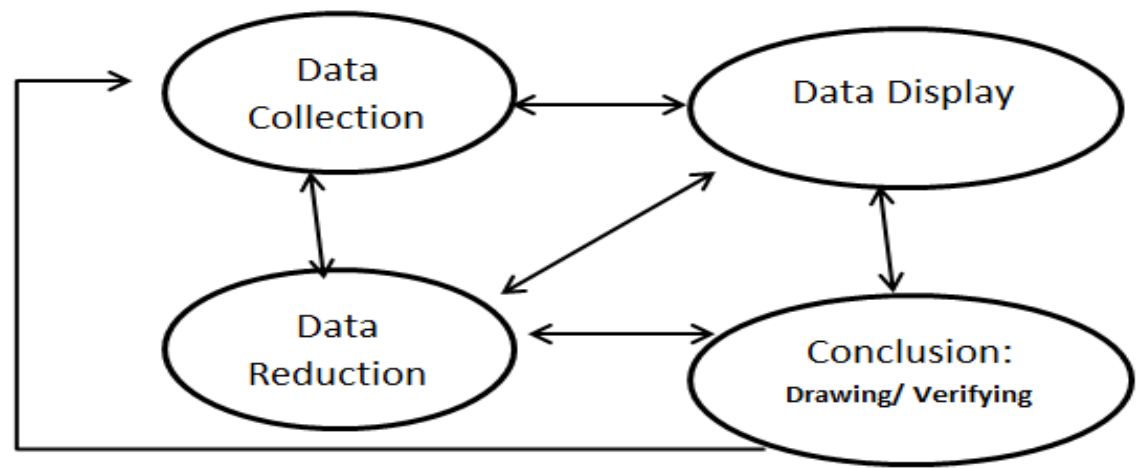

Gambar 1. Kompenen dalam analisis data (interactive model).

\section{Data Collection (Koleksi Data)}

Pada langkah ini aktivitas penelitian difokuskan pada pengumpulan data lapangan. Selama mengumpulkan data di lapangan akan diperoleh data yang cukup banyak. Semakin lama peneliti ke lapangan maka data akan semakin banyak, kompleks dan rumit, oleh karena itu pada tahap selanjutnya akan dilakukan tahap reduksi data.

\section{Data Reduction (Reduksi Data)}

Pada tahap ini aktivitas penelitian adalah merangkum, memilih hal-hal pokok, memfokuskan pada hal-hal penting, mencari tema dan pola berdasarkan data yang diperoleh dari lapangan seperti cara mengajar guru dalam menerangkan materi sistem koordinat, perhatian guru terhadap siswa yang mengalami kesulitan dalam mempelajari materi sistem koordinat, usaha guru untuk meningkatkan pemahaman siswa pada pembelajaran matematika materi sistem koordinat, menganalisis motivasi siswa untuk mengikuti pembelajaran matematika terutama pada materi sistem koordinat, mentukan titik koordinat, menggambar suatu bidang atau bangun ruang pada koordinat. Serta halhal lain yang disinyalir merupakan penyebab kesulitan siswa dalam mempelajari materi sistem koordinat dan hasil belajar siswa pada pembelajaran matematika materi sistem koordinat.

\section{Data Display (Penyajian Data)}

Setelah melakukan pengumpulan dan reduksi data, tahap selanjutnya adalah menyajikan data. Penyajian data dilakukan untuk memudahkan memahami apa yang terjadi di lapangan dan disajikan dalam bentuk deskriptif, yaitu hasil pengamatan yang 
diperoleh dari lapangan tentang kesulitan-kesulitan belajar siswa dalam memahami materi sistem koordinat pada pelajaran matematika dan hal-hal yang menyebabkan kesulitan tersebut.

\section{Conclusion Drawing/verification}

Kesimpulan dalam penelitian kualitatif adalah temuan baru yang sebelumnya belum pernah ada. Temuan tersebut dapat berupa deskripsi atau gambaran suatu objek yang sebelumnya masih remang-remang atau gelap sehingga menjadi jelas, dapat berupa hubungan kausal atau interaksi, hipotesis, atau teori. Langkah selanjutnya adalah membuat kesimpulan dari hasil analisis data yang diperoleh selama di lapangan, yaitu simpulan mengenai faktor penyebab kesulitan yang dialami siswa dalam mempelajari materi sistem koordinat pada mata pelajaran matematika.

\subsection{Instrumen Penelitian dan Teknik Pengumpulan Data}

Dalam penelitian kualitatif, yang berperan sebagai instrumen adalah peneliti sendiri. Nasution (dalam Prastowo, 2012: 23) menyatakan bahwa peneliti adalah key instrument atau alat peneliti utama. Sementara itu, teknik pengumpulan data penelitian ini adalah wawancara, observasi, dan dokumentasi.

\subsection{Instrumen Pengumpulan Data}

\section{Wawancara}

Wawancara dilakukan terhadap Wali Kelas V dan siswa yang mengalami kesulitan dalam mempelajari materi sistem koordinat.

2. Observasi

Observasi ini dilakukan terhadap siswa dan Wali Kelas $\mathrm{V}$ pada saat proses pembelajaran matematika materi sistem koordinat dengan menggunakan pedoman observasi dan mencatat hal-hal penting yang berkaitan dengan penelitian. Melalui observasi ini diharapkan peneliti dapat mengumpulkan data mendalam tentang penyebab siswa mengalami kesulitan belajar matematika dan jenis-jenis kesulitan belajar siswa pada materi sistem koordinat Kelas V di SDIT Widya Cendekia sehingga dapat memecahkan permasalahan yang diteliti.

Tabel 1. Teknik pengumpulan data

\begin{tabular}{|c|c|c|c|}
\hline No & Instrumen & $\begin{array}{l}\text { Sumber } \\
\text { informasi }\end{array}$ & Aspek yang di analisis \\
\hline \multirow[t]{2}{*}{1} & Wawancara & 1) Guru & $\begin{array}{l}\text { a. Motivasi belajar Matematika } \\
\text { b. Kesulitan belajar matematika } \\
\text { c. Jenis-jenis kesulitan belajar Matematika }\end{array}$ \\
\hline & & 2) Siswa & $\begin{array}{l}\text { a. Motivasi belajar Matematika } \\
\text { b. Pemahaman terhadap materi sistem } \\
\text { koordinat pada pelajaran Matematika } \\
\text { c. Kesulitan memahami materi sistem } \\
\text { koordinat pada pelajaran Matematika } \\
\text { d. Kemampuan terhadap materi sistem } \\
\text { koordinat pada pelajaran matematika }\end{array}$ \\
\hline 2 & Observasi & 3) Guru & $\begin{array}{l}\text { a. Persiapan pembelajaran } \\
\text { b. Penampilan guru } \\
\text { a. Memulai pembelajaran } \\
\text { b. Pelaksanaan evaluasi atau tes }\end{array}$ \\
\hline
\end{tabular}




\begin{tabular}{llll}
\hline \hline 4) Siswa & $\begin{array}{l}\text { a. Kedisiplinan siswa } \\
\text { b. Keaktifan selama proses pembelajaran } \\
\text { c. Pemahaman siswa terhadap materi yang } \\
\text { diajarkan }\end{array}$ \\
\hline 5) & $\begin{array}{l}\text { Hasil } \\
\text { pekerjaan } \\
\text { siswa }\end{array}$ & $\begin{array}{l}\text { a. Mengidentifikasi jenis-jenis kesalahan } \\
\text { dalam mengerjakan soal } \\
\text { b. Mengidentifikasi miskonsepsi atas } \\
\text { kesalahan siswa dalam pengerjaan soal }\end{array}$ \\
\hline
\end{tabular}

\subsection{Analisis Data}

Data yang dianalisis dalam penelitian ini berbentuk deskriptif, yaitu hasil pengumpulan data melalui instrumen yang dianalisis dan disajikan dalam bentuk deskriptif.

Semua hasil analisis disajikan dalam bentuk deskriptif, analisis dilakukan dengan memahami gejala yang ditemukan selama melakukan observasi dan mengaitkannya dengan teori yang relevan sehingga gejala dan kasus yang diteliti tersebut dapat dipahami.

\subsection{Validitas Data}

Uji kredibilitas data atau kepercayaan hasil penelitian kualitatif dilakukan dengan beberapa cara, seperti: perpanjangan pengamatan, peningkatan ketekunan dalam penelitian, tringulasi, diskusi dengan teman sejawat, analisis kasus negatif, dan memberchek (Soegiyono, 2015: 270). Pengujian keabsahan data pada penelitian ini dengan cara sebagai berikut:

1. Meningkatkan ketekunan yang berarti dilakukan pengamatan secara lebih cermat dan berkesinambungan, dengan melakukan hal ini maka akan diketahui apakah data yang ditemukan itu salah atau tidak.

2. Menggunakan bahan referensi atau pendukung untuk membuktikan data yang telah ditemukan seperti dokumentasi selama penelitian dilakukan.

\section{Hasil dan Pembahasan}

\subsection{Hasil}

\subsubsection{Data Hasil Tes}

Untuk memperoleh data tentang kesulitan belajar siswa dalam memahami materi sistem koordinat pada pelajaran matematika di Kelas V SDIT Widya Cendekia Tahun Ajaran 2018 maka dilakukan pemberian tes kepada 34 siswa. Hasil tes adalah sebagai berikut.

Tabel 2. Hasil tes untuk mengukur kesulitan belajar

\begin{tabular}{llllll}
\hline \multirow{2}{*}{ No } & \multirow{2}{*}{ Kriteria } & \multicolumn{2}{l}{ Tidak mengalami kesulitan } & \multicolumn{2}{l}{ Mengalami Kesulitan } \\
\cline { 3 - 6 } & & Banyak Siswa & Persentase (\%) & Banyak Siswa & Persentase (\%) \\
\hline 1 & K1 & 17 & 50.00 & 17 & 50.00 \\
\hline 2 & K2 & 16 & 47.06 & 18 & 52.94 \\
\hline 3 & K3 & 16 & 47.06 & 18 & 52.94 \\
\hline 4 & K4 & 9 & 26.47 & 25 & 73.53 \\
\hline 5 & K5 & 7 & 20.59 & 27 & 79.41 \\
\hline 6 & K6 & 21 & 61.76 & 13 & 38.24 \\
\hline
\end{tabular}




\begin{tabular}{llllll}
\hline 7 & K7 & 19 & 55.88 & 15 & 44.12 \\
\hline 8 & K8 & 19 & 55.88 & 15 & 44.12 \\
\hline 9 & K9 & 12 & 35.29 & 22 & 64.71 \\
\hline 10 & K10 & 16 & 47.06 & 18 & 52.94 \\
\hline
\end{tabular}

Keterangan:

Aspek-aspek keriteria kesulitan belajar siswa yang dianalisis berdasarkan soal.

$\mathrm{K}=$ kriteria

$\mathrm{K} 1=$ Menggambar titik koordinat

$\mathrm{K} 2$ = Menggambar titik absis

K3 = Menggambar titik ordinat

K4 = Menggambar bangun datar pada bidang koordinat

K5 = Menentukan suatu gambar bangun datar berdasarkan titik koordinat

K6 = Menentukan titik koordinat berdasarkan gambar

K7 = Menentukan letak titik koordinat

K8 = Menentukan letak absis pada titik 0

K9 = Menentukan letak titik pada absis 1

$\mathrm{K} 10=$ Menentukan letak titik pada ordinat 0

\subsubsection{Analisis Kesulitan Belajar Siswa dalam Memahami Materi Sistem Koordinat}

Penilaian tes diberikan dengan menggunakan rubrik kesulitan belajar siswa. Berdasarkan hasil tes tersebut data kesulitan belajar siswa dalam mempelajari materi sistem koordinat adalah sebagai berikut:

a. Menggambar titik koordinat

Terdapat 17 atau 50\% siswa yang mengalami kesulitan dalam menggambarkan titik koordinat, sisanya 17 atau 50\% siswa tidak mengalami kesulitan dalam menggambarkan titik koordinat.

b. Menggambar titik absis

Terdapat 18 atau 52\% siswa yang mengalami kesulitan dalam menggambarkan dan menentukan absis pada titik koordinat, sisanya 16 atau $48 \%$ siswa tidak mengalami kesulitan dalam menggambarkan dan menentukan absis pada titik koordinat.

c. Menggambar titik ordinat

Terdapat 18 atau 52\% siswa yang mengalami kesulitan dalam menggambarkan dan menentukan ordinat pada titik koordinat, sisanya 16 atau $48 \%$ siswa tidak mengalami kesulitan dalam menggambarkan dan menentukan ordinat pada titik koordinat.

d. Menggambar bangun datar yang terbentuk dari suatu titik koordinat dengan angka bilangan positif

Terdapat 25 atau $73 \%$ siswa yang mengalami kesulitan dalam menggambar bangun datar pada bidang koordinat dengan angka bilangan positif, sisanya hanya 9 atau $27 \%$ siswa yang tidak mengalami kesulitan dalam menggambar bangun datar pada titik koordinat dengan angka bilangan positif.

e. Menentukan suatu gambar bangun datar yang terbentuk dari suatu titik koordinat dengan angka bilangan positif dan negatif

Terdapat 27 atau 79\% siswa yang mengalami kesulitan dalam menentukan gambar bangun datar pada bidang koordinat yang terbentuk dari suatu titik dengan angka bilangan positif dan negatif, sisanya hanya 7 atau $21 \%$ siswa yang tidak mengalami 
kesulitan dalam menentukan gambar bangun datar pada bidang koordinat yang terbentuk dari suatu titik dengan angka bilangan positif dan negatif .

f. Menentukan titik koordinat berdasarkan gambar bangun datar dalam bidang koordinat

Terdapat 13 atau 38\% siswa yang mengalami kesulitan dalam menentukan titik koordinat berdasarkan gambar bangun datar dalam bidang koordinat, sisanya sedangkan 21 atau 38\% siswa tidak mengalami masalah dalam menentukan titik koordinat berdasarkan gambar bangun datar dalam bidang koordinat.

g. Menentukan letak titik koordinat

Terdapat 15 atau 44\% siswa yang mengalami kesulitan dalam menentukan letak titik koordinat, sisanya 19 atau 56\% siswa tidak mengalami masalah dalam menentukan letak titik koordinat.

h. Menentukan letak absis pada titik 0

Terdapat 15 atau 44\% siswa yang mengalami kesulitan dalam menentukan letak absis pada titik 0, sisanya 19 atau 56\% siswa mampu tidak mengalami kesulitan dalam menentukan letak absis titik pada titik 0 .

i. Menentukan letak titik pada absis titik 1

Terdapat 22 atau 64\% siswa yang mengalami kesulitan dalam menentukan letak absis pada titik 1, sisanya 12 atau $36 \%$ siswa tidak mengalami kesulitan dalam menentukan letak absis pada titik 1.

j. Menentukan letak titik pada ordinat titik 0

Terdapat 18 atau 52\% siswa yang mengalami kesulitan dalam menentukan letak ordinat pada titik 0 , sisanya 16 atau $48 \%$ siswa tidak mengalami kesulitan dalam menentukan letak ordinat pada titik 0 .

Berdasarkan data yang diperoleh dari observasi, wawancara, dan pengumpulan dokumen berupa hasil tes siswa serta hasil analisis melalui rubrik kesulitan belajar siswa dalam memahami materi sistem koordinat, kesulitan-kesulitan tersebut diklasifikasikan ke dalam empat jenis kesulitan belajar yaitu, kesulitan dalam menggambarkan atau menentukan titik koordinat, menggambarkan atau menentukan bangun datar pada titik koordinat, menentukan absis, dan kesulitan dalam menentukan ordinat.

Jenis yang pertama yaitu menggambarkan titik koordinat. Berdasarkan jawaban hasil tes siswa pada Soal Nomor 1 beberapa siswa mengalami kesulitan dalam menggambarkan titik koordinat. Sebagaimana yerlihat pada pada Gambar 2 berikut. Siswa diminta menentukan koordinat titik A $(2,3)$; titik B $(5,3)$; titik C $(-3,-1)$; dan titik D $(-5,5)$. Siswa menjawab dengan jawaban beragam, salahsatunya disajikan pada gambar di bawah. 


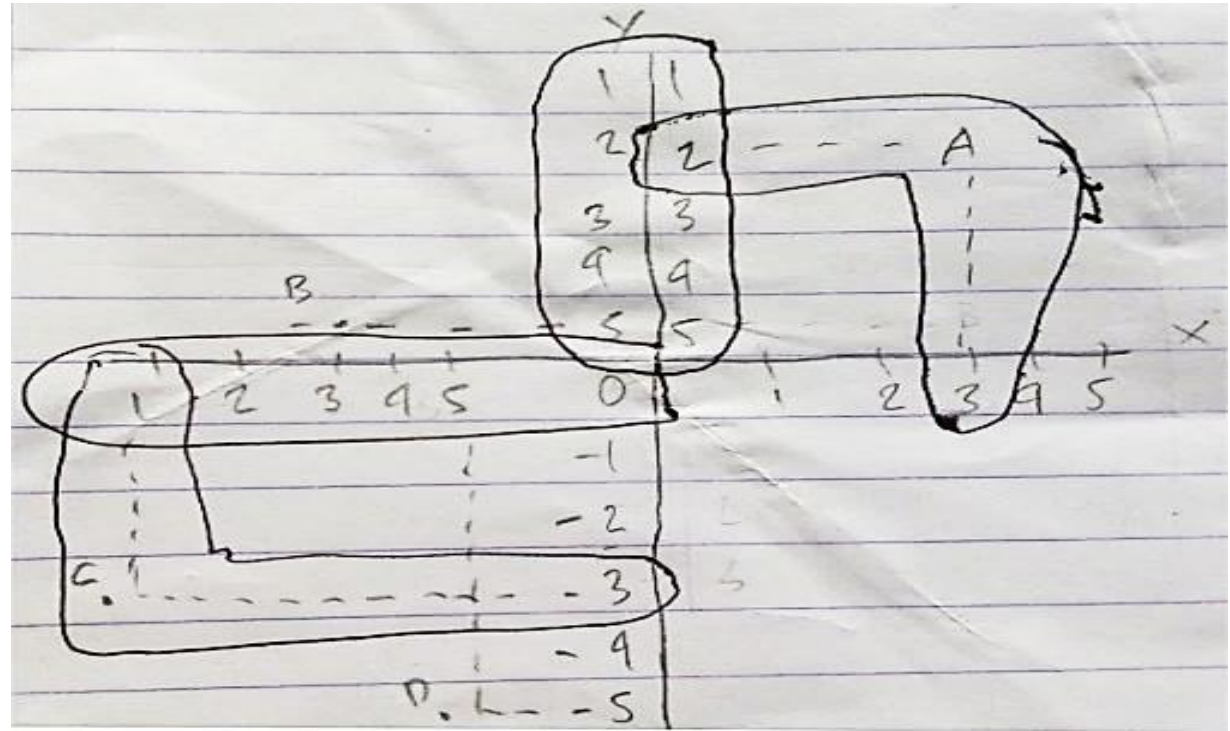

Gambar 2. Hasil pekerjaan siswa yang menunjukkan kesalahan dalam menggambarkan kompenen titik koordinat.

Siswa salah menentukan letak koordinat titik A. Seharusnya menggambarkan titik $(2,3)$ tetapi siswa menggambarkan koordinat titik A di $(3,2)$. Berdasarkan hasil wawancara terhadap siswa yang bersangkutan diperoleh informasi bahwa siswa tersebut memiliki miskonsepsi dalam menentukan titik koordinat. Siswa beranggapan bahwa urutan menuliskan komponen sebuah titik adalah komponen Sumbu Y terlebih dahulu baru kemudian komponen Sumbu X. Selain itu, terlihat juga pada gambar di atas, siswa melakukan kesalahan dalam mengurutkan bilangan pada garis bilangan. Siswa kemudian diminta menuliskan urutan bilangan pada garis bilangan ada beberapa siswa yang tidak bisa menuliskan urutan garis bilangan dengan benar. Artinya siswa belum memahami konsep urutan bilangan bulat yang berakibat kesalahan pada penulisan bilangan di garis bilangan.

Jenis kesalahan yang sama juga terlihat pada Gambar 3, yaitu siswa melakukan kesalahan dalam meletakkan bilangan negatif pada Sumbu Y yang seharusnya di sisi kiri, tetapi siswa menuliskannya di sisi kanan. Kesalahan yang lain adalah dalam menentukan titik koordinat $(-5,5)$ jawaban siswa adalah $(-5,-5)$. Selanjutnya adalah ketidakjelian siswa dalam membaca instruksi soal. Intruksi Soal Nomor 1 meminta siswa menggambarkan letak titik A, B, C, dan D saja. Akan tetapi, terlihat pada gambar siswa juga menuliskan titik $\mathrm{R}$ dan $\mathrm{S}$ dan menggabungkan Soal Nomor 2 dan 3 dalam satu bidang koordinat. 


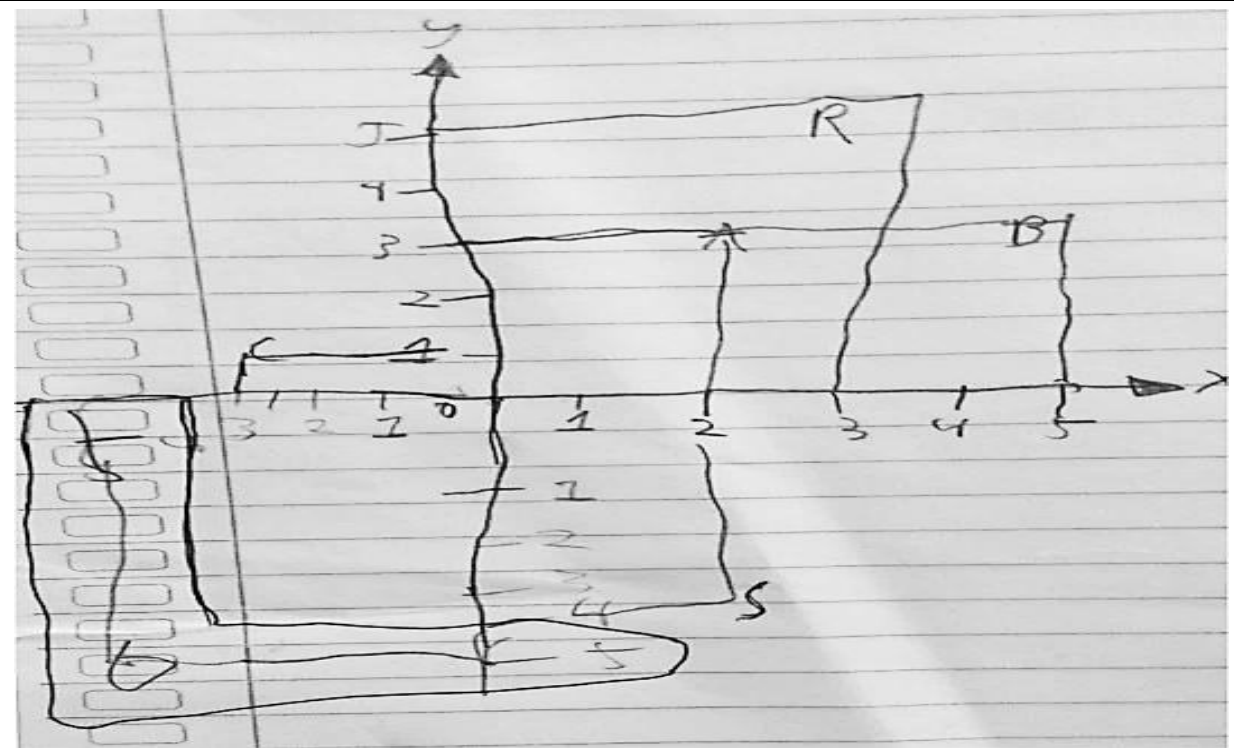

Gambar 3. Hasil pekerjaan siswa yang menunjukkan kesalahan dalam menggambarkan titik koordinat.

Jenis kesalahan selanjutnya terlihat pada Gambar 4. Kesalahan berikut sama seperti jenis kesalahan pertama yaitu kesalahan dalam mengurutkan bilangan pada garis bilangan di Sumbu Y. Siswa menuliskan 0 kemudian langsung ke angka terbesar yaitu 5. Kemudian dalam menentukan koordinat titik A yang seharusnya $(2,3)$ siswa menjawab $(-3,2)$ dan koordinat titik B yang seharusnya $(5,3)$ siswa menjawab $(-3,5)$. Berdasarkan hasil wawancara terhadap siswa yang bersangkutan diperoleh informasi bahwa siswa mengalami kebingungan dalam menentukan titik koordinat dikarenakan siswa tidak bisa membedakan tanda bilangan negatif dan positif.

Secara umum kesalahan siswa dalam menjawab Soal Nomor 1 adalah dalam menentukan pasangan titik absis dan ordinat, di mana seharusnya merupakan urutan absis-ordinat, kebanyakan siswa menuliskan ordinat-absis. Siswa juga mengatakan bahwa mereka belum memahami konsep koordinat. Kesalahan lain yang terlihat adalah dalam mengurutkan bilangan negatif dan positif, yang menunjukkan bahwa siswa belum bisa membandingkan nilai bilangan negatif saat dibandingkan dengan bilangan positif.

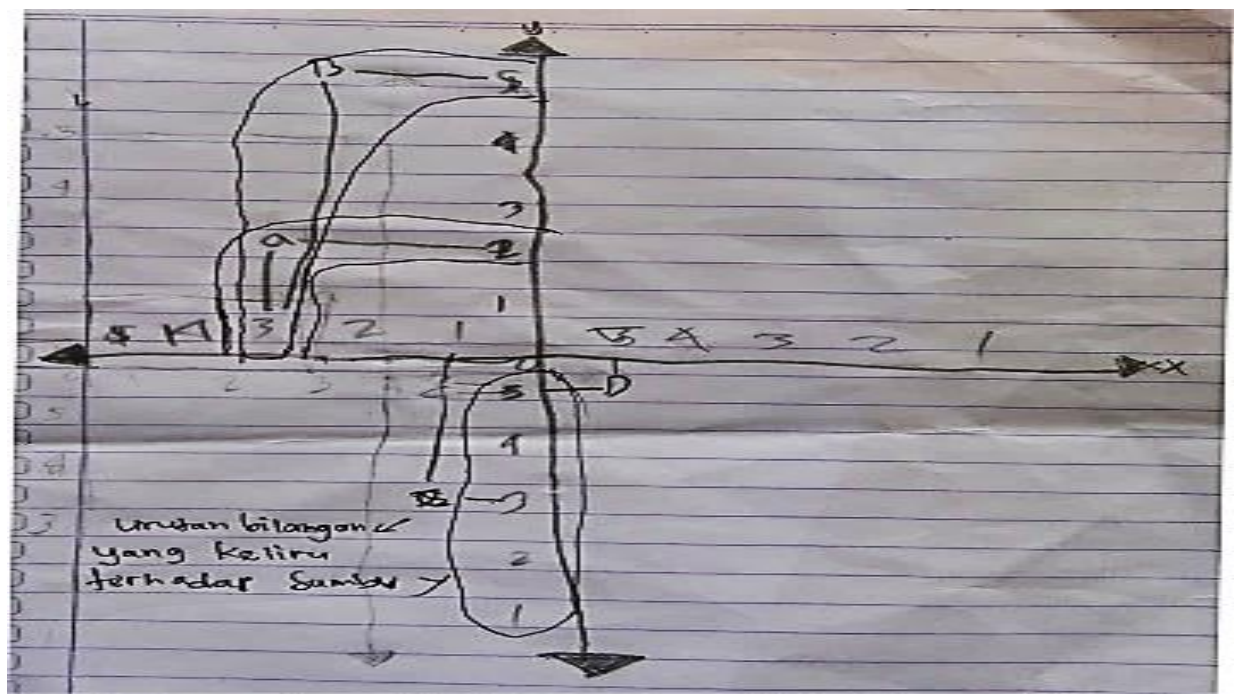

Gambar 4. Hasil pekerjaan siswa yang menunjukkan kesalahan menentukan urutan bilangan pada sumbu koordinat 
Jenis kesalahan selanjutnya yaitu dalam menentukan komponen absis sebuah koordinat. Pada Soal Nomor 2 siswa diminta menentukan komponen absis dari koordinat titik $\mathrm{R}$, yaitu $(3,5)$. Untuk titik $\mathrm{R}$ sendiri, kebanyakan siswa menggambarkannya seperti pada Gambar 5. Beberapa siswa menggambarkan titik tersebut dengan posisi terbalik. Untuk menentukan absis-nya sendiri beberapa siswa menjawab 3 dan siswa lain menjawab 5. Berdasarkan hasil wawancara terhadap siswa diperoleh informasi bahwa siswa tidak memahami absis dan ada pula yang keliru dalam menentukan antara absis dan ordinat. Ada juga yang lupa apa itu absis dan ordinat atau tidak tahu. Hal ini menunjukkan bahwa kesalahan ini terjadi karena siswa memiliki pengetahuan atau konsep yang keliru.

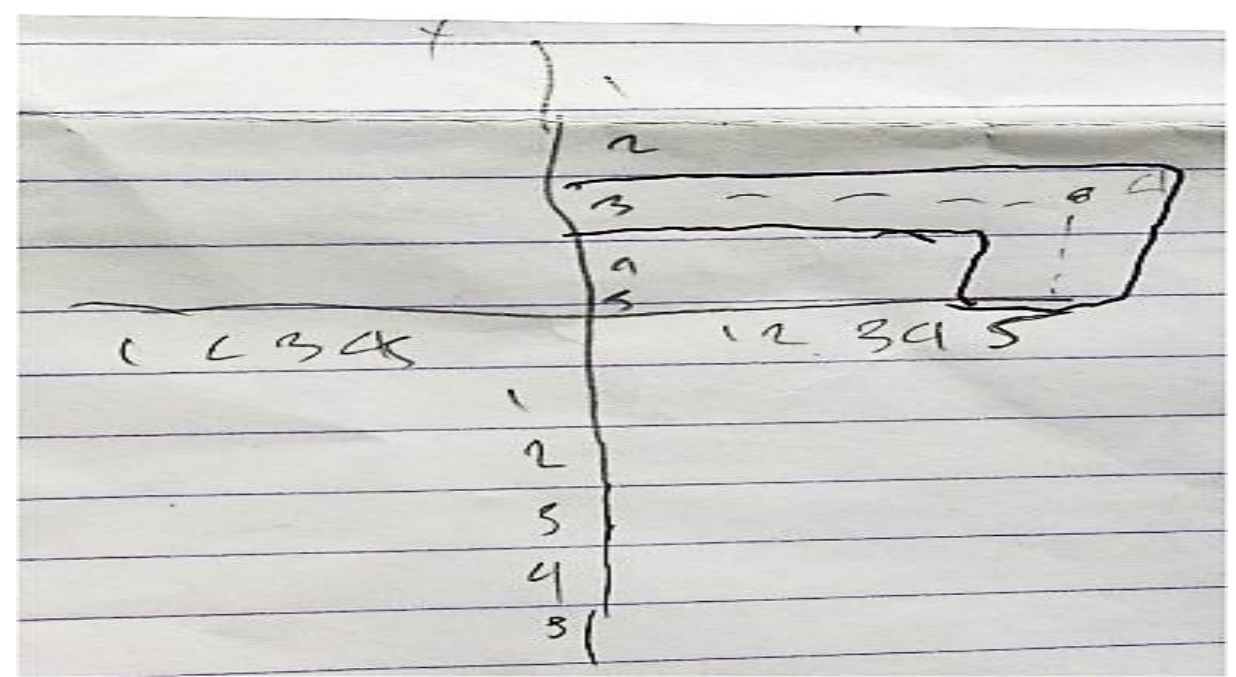

Gambar 5. Hasil pekerjaan siswa yang menunjukkan kesalahan menentukan komponen absis sebuah titik.

Selanjutnya adalah kesalahan dalam menetukan ordinat. Pada Soal Nomor 3 siswa diminta menentukan ordinat dari titik $S$ dengan koordinat $(-2,4)$. Kebanyakan siswa menggambarkan titik $S$ dengan koordinat $(4,2)$ dan jawaban siswa adalah 2. Kesalahan ini terjadi dengan sebab yang sama seperti pada kesalahan sebelumnya.

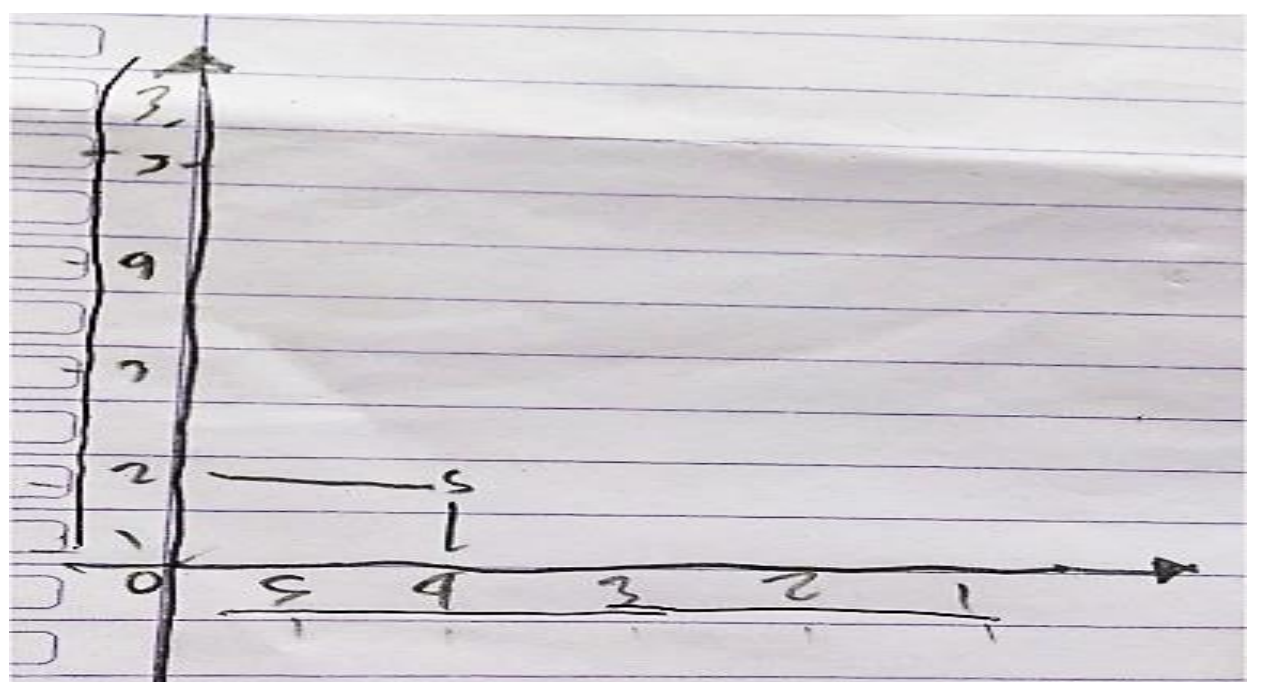


Gambar 6. Hasil pekerjaan siswa yang menunjukkan kesalahan menentukan komponen ordinat sebuah titik.

Selanjutnya kesalahan dalam menggambar atau menentukan bangun datar pada bidang koordinat. Pada Soal Nomor 4 siswa diminta menggambar bangun datar yang dibentuk oleh titik-titik $\mathrm{P}(1,3)$; $\mathrm{Q}(1,1)$; dan $\mathrm{R}(4,1)$. Ketiga titik ini sedianya membentuk sebuah bangun segitiga siku-siku. Akan tetapi siswa tidak menggambarkan seperti yang diminta seperti yang terlihat pada Gambar 7.

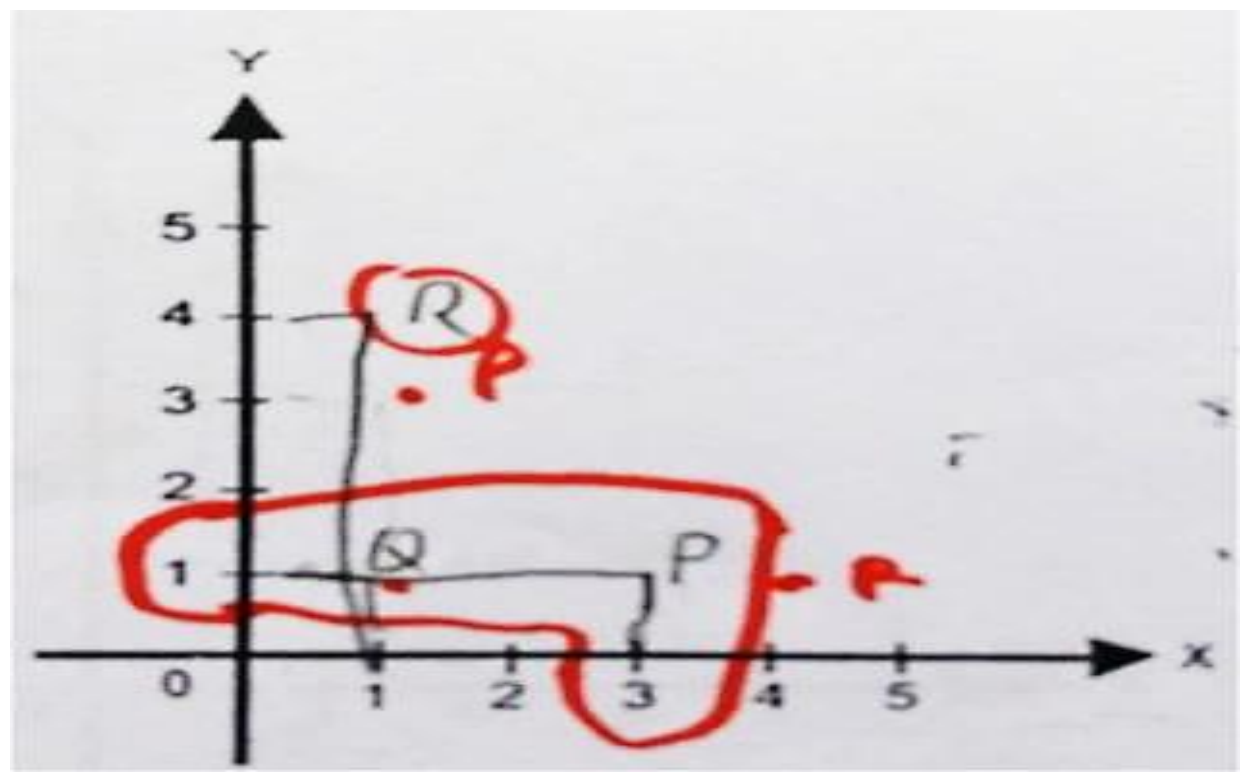

Gambar 7. Hasil pekerjaan siswa yang menunjukkan kesalahan dalam menggambar bangun datar pada bidang koordinat kartesius.

Pada Soal Nomor 5 siswa diminta menggambarkan bangun datar yang dibentuk oleh titik-titik dengan koordinat $(3,-2) ;(1,2) ;(-3,2)$; dan $(-3,-1)$. Keempat titik ini seharusnya membentuk sebuah bangun jajar genjang. Namun terlihat pada Gambar 8, siswa tidak menggambar sesuai dengan yang diharapkan. Berdasarkan wawancara dengan siswa yang bersangkutan diperoleh informasi bahwa sebagian besar siswa mengalami kesulitan dalam menggambarkan bangun datar pada bidang koordinat kartesius dikarenakan siswa masih belum bisa menentukan koordinat setiap titik pada bidang kartesius dengan benar. Beberapa siswa juga ada yang keliru dalam menentukan urutan bilangan dan menentukan posisi bilangan negatif dan positif pada sumbu koordinat. Secara umum siswa mengalami kesulitan menentukan bangun datar yang terbentuk karena siswa belum memahami bagaimana cara menentukan titik pada bidang kartesius. 


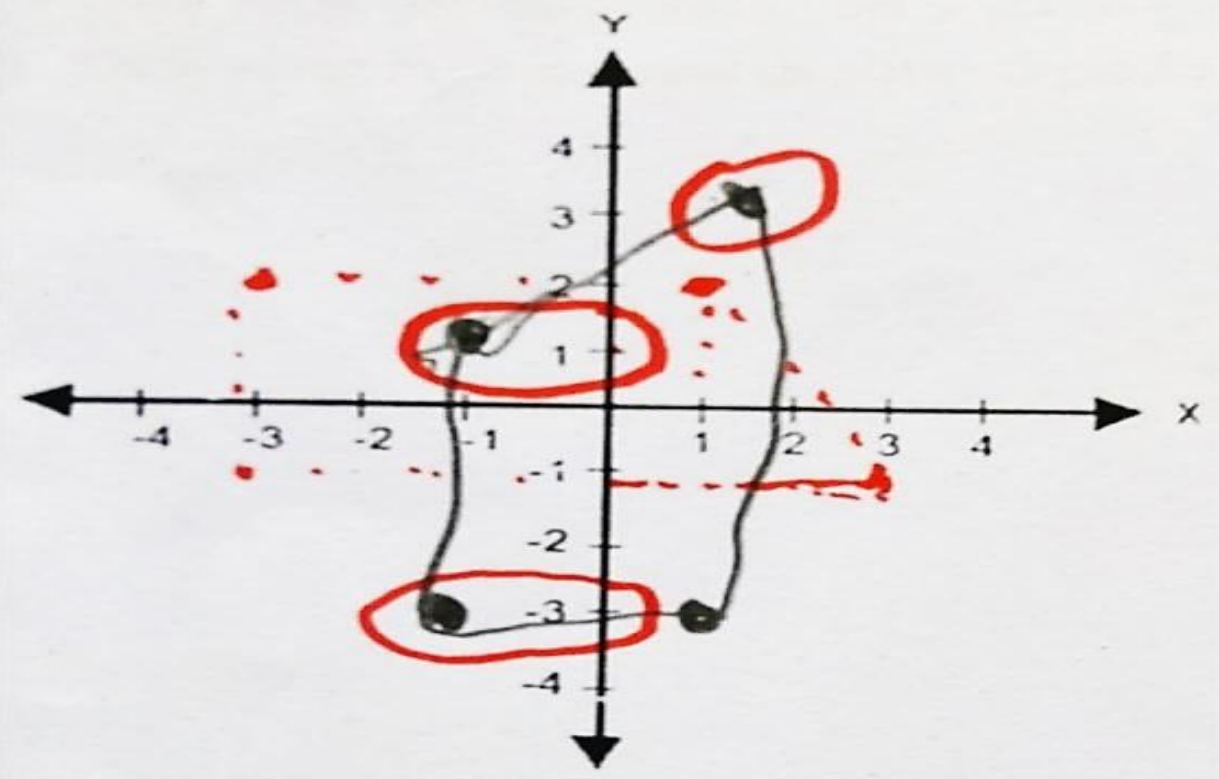

Gambar 8. Hasil pekerjaan siswa yang menunjukkan kesalahan dalam menggambar bangun datar pada bidang kartesius.

Gambar 9 menunjukkan kesalahan dalam menentukan koordinat dari titik-titik yang ditunjukkan pada gambar yang sudah ada. Kesalahan ini terjadi karena siswa belum memahami posisi titik dan terdapat miskonsepsi mengenai komponen sebuah titik pada bidang koordinat kartesius.

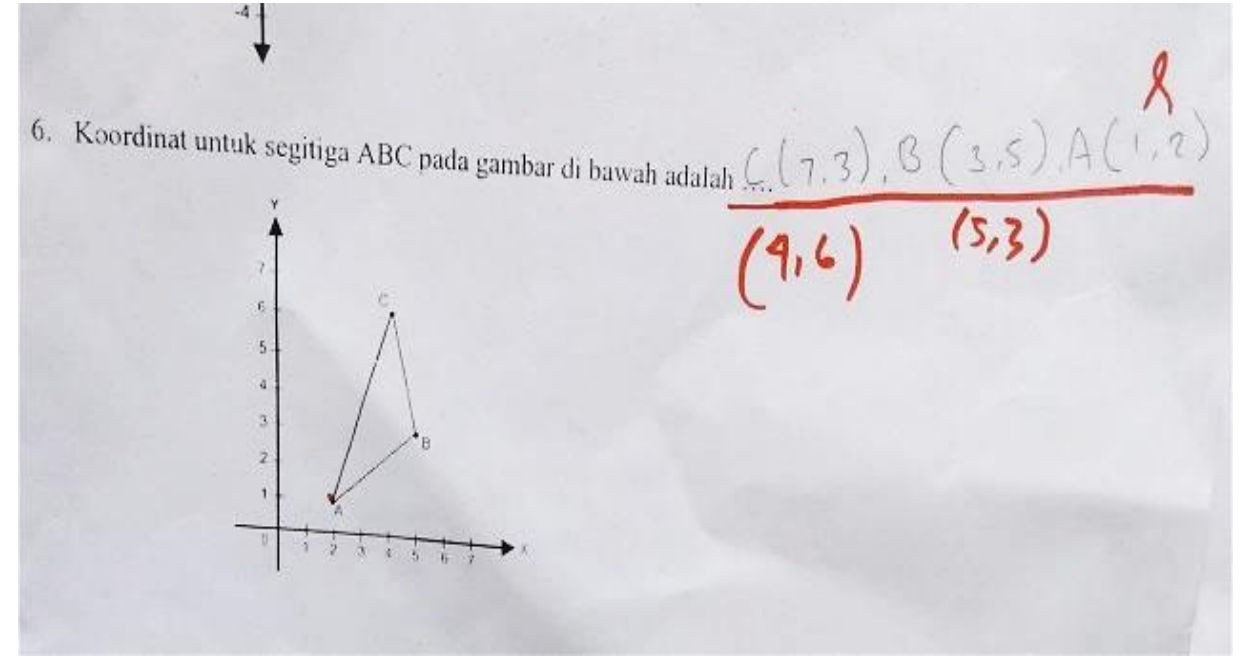

Gambar 9. Hasil pekerjaan siswa yang menunjukkan kesalahan dalam menentukan koordinat dari sebuah titik pada bidang kartesius.

Pada Soal Nomor 7 sampai dengan Nomor 10 siswa diminta menentukan nama titik berdasarkan informasi yang diberikan pada gambar. Pada Gambar 10 terlihat bahwa siswa masih belum bisa menentukan nama titik dengan absis dan ordinat tertentu. Berdasarkan wawancara terhadap siswa diperoleh informasi bahwa sebagian siswa banyak yang belum memahami konsep absis dan ordinat. 
Pertanyaan nomor 7 s.d 10 berdajarkan gambar berikut !

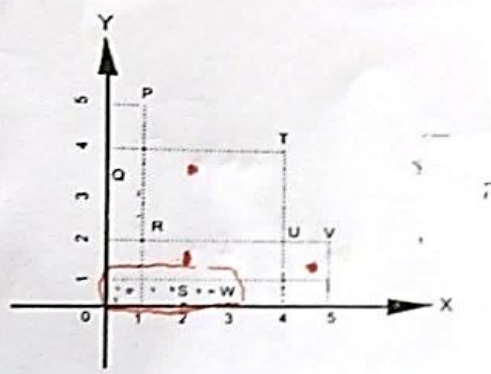

7. Koordinat $(3,0)$ pada gambar di atas ditunjukan oleh titik $W$

8. Titik yang mempunyai absis 0 pada gambar di atas ditunjukan oleh titik $Q$

9. Titik yang mempunyai absis 1 pada gambar di atas adalah titik $K R \quad \mathbb{R} P$

10. Titik yang mempunyai ordinat 0 pada gambar di atas adalah titik $w,(Q)$

Gambar 10. Hasil pekerjaan siswa yang menunjukkan kesalahan dalam menentukan titik-titik koordinat pada gambar.

\subsection{Pembahasan}

\subsubsection{Faktor-Faktor Kesulitan Belajar Siswa}

Berdasarkan hasil observasi dan wawancara dengan guru dan siswa, serta tes yang diberikan kepada Siswa Kelas V SDIT Widya Cendekia terdapat beberapa faktor yang mempengaruhi siswa berkesulitan belajar. Faktor-faktor tersebut kemudian dikategorikan ke dalam faktor internal dan faktor eksternal. Berikut ini penjelasannya.

1) Faktor internal

Beberapa faktor internal yang memengaruhi kesulitan belajar Matematika antara lain sikap dalam belajar matematika. Sikap positif terhadap suatu pembelajaran adalah awal yang baik untuk proses pembelajaran selanjutnya. Sebaliknya sikap negatif akan berpotensi menimbulkan kesulitan belajar atau memberikan hasil yang kurang maksimal. Beberapa orang siswa menyatakan tidak menyukai pelajaran matematika. Hal ini memberikan persepsi negatif terhadap pembelajaran Matematika. Siswa menganggap matematika adalah pelajaran yang sulit. Mereka juga tidak antusias menerima materi yang disampaikan. Selain itu juga mengakibatkan rendahnya minat dan motivasi siswa dalam belajar Matematika. Siswa juga tidak aktif dalam mengikuti pembelajaran matematika yang diberikan oleh guru. Siswa seringkali tidak memperhatikan guru ketika guru menjelaskan materi, masih mengobrol dengan teman sebelahnya atau sibuk sendiri.

Kemudian faktor fisiologis yakni kesehatan fisik siswa yang berdampak pada kurangnya konsentrasi belajar dan mengantuk. Ketika kondisi fisik tidak dalam keadaan optimal siswa tidak bisa menangkap materi yang disampaikan dengan baik. Selain itu, terdapat beberapa miskonsepsi sebagai berikut.

- menentukan komponen sebuah koordinat pada bidang kartesius. Siswa beranggapan bahwa untuk menggambarkan sebuah titik, yang dituliskan terlebih dahulu adalah pasangan titik pada komponen Sumbu Y (ordinat) baru kemudian komponen pada Sumbu X (absis).

- menentukan urutan bilangan pada garis bilangan, yang berakibat kesalahan menuliskan urutan pada Sumbu X dan Sumbu Y.

- menentukan urutan bilangan pada garis bilangan atau sumbu kartesius. Siswa 
beranggapan bahwa ujung Sumbu Y atau X ditempati oleh angka terkecil.

Faktor internal yang lain adalah siswa tidak atau belum menguasai materi atau pengetahuan prasyarat untuk belajar sistem koordinat kartesius. Pengetahuan prasyarat untuk mempelajari materi sistem koordinat kartesius adalah sebagai berikut: memahami konsep titik, memahami konsep garis, memahami konsep bilangan positif dan negatif, memahami konsep urutan bilangan positif dan negatif, memahami konsep garis bilangan, memahami sumbu-sumbu koordinat, menentukan titik pusat $(0,0)$, memberi nama pada titik (absis, ordinat), menentukan titik koordinat, menggambarkan suatu bidang datar pada koordinat.

Berdasarkan temuan-temuan yang telah disampaikan, sebagian besar siswa belum menguasai pengetahuan-pengetahuan yang dibutuhkan untuk mempelajari sistem koordinat seperti pemahaman tentang titik, garis, bilangan, urutan pada bilangan, dan garis bilangan. Hal ini mengakibatkan kesulitan siswa untuk mengubah pengetahuan awal yang sudah dimiliki untuk membangun pengetahuan baru mengenai koordinat kartesius. Dengan kata lain, kesulitan siswa dalam mempelajari materi koordinat kartesius secara garis besar karena siswa belum menguasai pengetahuan prasyarat untuk mempelajari materi tersebut.

\section{2) Faktor Eksternal}

Berdasarkan hasil wawancara terhadap siswa, salah satu faktor eksternal siswa berkesulitan belajar adalah berasal dari keluarga. Keluarga belum mendukung aktivitas belajar secara optimal yang ditandai dengan kurangnya latihan atau mengulang pelajaran di rumah atau tidak mengikutsertakan siswa pada jam belajar tambahan. Faktor eksternal yang lain adalah pada metode atau strategi pembelajaran yang digunakan oleh guru untuk menyampaikan materi ini. Kebanyakan guru menyampaikan materi geometri menggunakan pendekatan yang sama dengan cara menyampaikan materi mengenai bilangan. Padahal pola pikir siswa untuk kedua jenis pokok bahasan ini tidak sama.

\subsubsection{Upaya untuk Mengatasi Kesulitan Belajar Siswa pada Pelajaran Matematika untuk Materi Sistem Koordinat}

1) Menyiapkan Mental Siswa untuk Belajar Matematika

Banyak anak berkesulitan belajar matematika yang penyebabnya adalah kurangnya kesiapan anak untuk mempelajari bidang studi tersebut. Adanya motivasi dan apersepsi sebelum memulai pembelajaran akan menunjang membangun semangat belajar dan jejaring pengetahuan siswa sebelum mempelajari konsep yang baru.

2) Menerapkan pembelajaran mulai dari yang konkret ke yang abstrak

Siswa dapat memahami konsep-konsep matematika dengan baik jika pembelajaran mulai dari yang konkret ke yang abstrak. Guru hendaknya merancang tiga tahapan belajar, yaitu konkret, representasional, dan abstrak. Pada tahapan konkret, siswa memanipulasi berbagai objek nyata dalam belajar keterampilan. Pada tahap representasional, suatu gambar dapat mewakili objek nyata. Sampai pada tahap abstrak, gambar atau simbol grafis akhirnya digantikan dengan angka.

3) Membangun Pengetahuan Prasyarat

Adakalanya siswa lupa atau bahkan belum mengetahui materi prasyarat yang dibutuhkan untuk mempelajari materi sistem koordinat. Untuk itu, pembelajaran dapat dimulai dengan mengulang materi untuk mengingatkan kembali atau menyampain materi prasyarat yang dibutuhkan untuk masuk ke materi sistem koordinat. Seperti yang 
telah disampaikan bahwa Matematika adalah ilmu yang berjenjang. Oleh karenanya, struktur pengetahuan pada matematika juga berjenjang di mana suatu konsep biasanya merupakan bangunan yang tersusun atas konsep-konsep sebelumnya dan konsep yang sedang dipelajari merupakan prasyarat untuk mempelajari konsep selanjutnya. Guru dapat menggunakan lembar kerja yang secara sistematis membangun pengetahuan siswa mengenai konsep yang akan dipelajari.

4) Memberi Kesempatan Kepada Siswa untuk Berlatih dan Mengulang

Dalam memahami suatu konsep tidak semua siswa dapat menerima dengan cepat dan mudah oleh sebab itu perlu adanya pengulangan penjelasan dan mengulang latihan soal agar siswa dapat menguasai suatu konsep matematika.

5) Melakukan Pembelajaran Remedial atau Tutorial

Berdasarkan pada prinsip pembelajaran matematika, pembelajaran remedial dalam matematika harus dilakukan. Pembelajaran remedial dipilih sebagai solusi yang ditawarkan karena didalam aktivitas pembelajaran remedial mencakup tiga kategori, yaitu konsep, keterampilan, dan pemecahan masalah. Apabila aktivitas pembelajaran didesain agar memuat ketiga kategori tersebut diharapkan dapat meminimalisir kesulitan belajar siswa.

6) Penggunaan Media Pembelajaran

Penggunaan media dalam pembelajaran matematika membantu siswa dalam menjembatani konsep matematika yang abstrak dengan pola pikir siswa yang konkret. Terdapat bebagai jenis media pembelajaran untuk materi sistem koordinat, contohnya adalah penggunaan media papan koordinat yang di harapkan dapat membantu mengatasi kesulitan belajar siswa pada materi sistem koordinat. Dengan menggunakan papan koordinat ini diharapkan siswa akan lebih mudah memahami konsep garis dan titik dan menentukan titik koordinat dan memudahkan siswa dalam menggambar bangun datar pada bidang kartesius.

7) Menerapkan Teori Belajar Van Hiele

Unsur utama dalam pengajaran geometri, yaitu waktu, materi pengajaran,dan metode pengajaran yang diterapkan. Jika ketiga unsur ditata secara terpadu, akan dapat meningkatkan kemampuan berpikir anak kepada tahapanberpikir yang lebih tinggi. Teori Van Hiele memiliki beberapa karakteristik sebagai berikut.

1. Belajar adalah proses yang tidak kontinu. Ini berarti terdapat loncatan di dalam kurva belajar yang memperlihatkan adanya celah yang secara kualitatif membedakan tingkatan berpikir. Siswa yang telah mencapai suatu tingkat, dia tetap pada tingkat itu untuk suatu waktu dan seolah-olah menjadi matang. Dengan demikian tidak akan banyak berarti apabila memberikan sajian kegiatan yang lebih tinggi dari tingkat yang dimiliki siswa.

2. Tingkatan Van Hiele bersifat hierarkis dan sekuensial. Untuk mencapai tingkat yang lebih tinggi, siswa harus menguasai sebagian besar tingkat sebelumnya. Kecepatan untuk berpindah dari suatu tingkat ke tingkat yang lebih tinggi lebih banyak bergantung pada isi dan metode pembelajaran dibandingkan dengan umur atau kematangan biologisnya.

3. Konsep yang secara implisit dipahami pada suatu tingkat menjadi eksplisit pada tingkat berikutnya. Misalnya pada tingkat visualisasi siswa mengenal bangun berdasarkan sifat bangun secara utuh, tetapi pada tingkat analisis, bangun tersebut dianalisis sehingga sifat-sifat serta komponennya ditemukan. 
4. Setiap tingkatan masing-masing mempunyai simbol bahasa tersendiri dan sistem yang mengaitkan simbol-simbol itu. Siswa tidak mudah mengerti penjelasan guru apabila guru berbicara pada tingkat yang lebih tinggi dari tingkat berpikir siswa. Hal ini mungkin akan memunculkan suatu masalah apabila tingkat sajian kegiatan, serta bahan pembelajaran tidak sesuai dengan tingkat berpikir siswa yang menggunakannya.

\section{Kesimpulan}

Berdasarkan uraian di atas dapat disimpulkan beberapa hal sebagai berikut.

1. Siswa yang mengalami kesulitan belajar matematika materi sistem koordinat di kelas V SDIT Widya Cendekia Kota Serang rata-rata sebanyak 54,8\%. Jenis kesulitannya meliputi: menggambar titik koordinat, menggambar titik absis, menggambar titik ordinat, menggambar bangun datar pada bidang koordinat, menentukan suatu gambar bangun datar berdasarkan titik koordinat, menentukan titik koordinat berdasarkan gambar, menentukan letak titik koordinat, menentukan letak absis pada titik 0, menentukan letak titik pada absis 1, menentukan letak titik pada ordinat 0. Secara umum ada empat jenis kesulitan siswa dalam memahami materi mistem koordinat yaitu kesulitan dalam menentukan titik koordinat, menggambarkan bangun datar pada bidang koordinat serta menentukan absis dan ordinat.

2. Faktor yang memengaruhi kesulitan belajar pada Siswa Kelas V di SDIT Widya Cendekia Kota Serang meliputi: sikap siswa yang belum semuanya positif, faktor psikologis dalam belajar, konsentrasi, miskonsepsi, dan materi prasyarat yang belum dikuasai. Selain itu adanya faktor eksternal yaitu kurangnya pendampingan belajar matematika di luar sekolah terutam dukungan keluarga dan metode pembelajaran yang belum tepat.

3. Upaya mengatasi kesulitan belajar siswa pada pelajaran matematika untuk materi sistem koordinat diantaranya yaitu perlunya menyiapkan mental anak untuk belajar matematika, membangun pengetahuan prasyarat, mulai dari yang konkret ke yang abstrak, memberi kesempatan kepada anak untuk berlatih dan mengulang, melakukan pengajaran remedial, menggunaan media pembelajaran, dan menerapkan teori belajar Van Hiele.

\section{Daftar Pustaka}

Mulyati. (2005). Psikologi Belajar. Jogjakarta: Andi Offset.

Nadhirah, Y. F., (2017). Psikologi Belajar dan Mengajar. Laporan Hasil Penelitian. Serang: Dinas Pendidikan Provinsi Banten.

Prastowo, A. (2012). Metode Penelitian Kualitatif dalam Perspektif Rancangan Penelitian. Jogjakarta: Ar-ruzz Media.

Purwanto, N. (2011). Psikologi Pendidikan. Bandung: Rosda Karya.

Soegiyono. (2015). Metode Penelitian Kuantitatif Kualitatif dan $R \& D$. Bandung: Alfabeta. 
Sundayana, R. (2016). Media dan Alat Praga dalam Pembelajaran Matematika. Bandung: Alfabeta.

Susanto, A. (2013). Teori Belajar Pembelajaran di Sekolah Dasar. Jakarta: Kencana Prenadamedia Group. 